\title{
Study on eggs of J apanese quail (Coturnix coturnix japonica) during incubation in the controlled laboratory conditions
}

\section{R. A. Patil Bhagat ${ }^{1}$, S. B. Zade ${ }^{1 *}$ and P. N. Char de}

${ }^{1}$ Post Graduate Teaching Department of Zoology, RTM Nagpur University, Campus, Amravati Road, Nagpur - 440033 , INDIA

${ }^{2}$ Sevadal Mahila Mahavidyalaya and Research Academy, Sakkardara Square, Nagpur- 440 033, INDIA

*Corresponding author. E-mail: profsbzade@rediffmail.com

\begin{abstract}
Study on newly laid eggs of Japanese quail Coturnix coturnix japonica was undertaken for a period of 18 days on incubation in controlled laboratory conditions. The aim of the study was to evaluate the changes in egg weight, shell weight, yolk weight and embryo weight throughout the period of incubation. It had been found that as the embryo grows, the egg weight slowly goes down while embryo weight goes on increasing day by day. The study inferred that the shift or reduction in weight of egg is attributable to the progressive growth of embryo which utilizes its yolk contents for its growth. Apart from this, the shell weight also reduced from first day to last day in order to facilitate hatching of the embryo.
\end{abstract}

Keywords: Coturnix coturnix japonica, Eggs, Incubation, Japanese quail, Shell weight

\section{NTRODUCTION}

The eggs of Japanese quail are artificially incubated in the laboratory under controlled conditions in a sophisticated incubator to assess the changes. The Japanese quail has been used for lab. studies (Padgett and Ivey, 1959; Wilson et al.,1961, Reese and Reese, 1962). Today work on coturnix is carried out by very few researchers across India (Woodard and Wilson, 1963, Charde, 1998) as well as abroad (Vasconcelos de Moraes et al., 2008).

In this context studies on eggs of Japanese quail Coturnix coturnix japonica were undertaken with respect to shell weight, embryo weight as well as yolk weight during a period of 18 days time in incubation.

\section{MATERIALS AND METHODS}

The freshly laid eggs of Japanese quail were procured from Chandrapur quaillary of Maharshtra state during 2010 for studies with respect to egg weight, shell weight, yolk weight and embryo weight. Digital electronic balance was used for recording the weights of the eggs. The eggs were marked and store pointed end down in incubator racks. Studies were made using incubator Cabinet Model of A.P. Equipment Hyderabad under controlled laboratory conditions at temp. $35^{\circ} \mathrm{C}$ and humidity $60 \%$. During incubation the tilting was done after every one hour. Tilting was stopped after 15 days of incubation.

\section{RESULTS AND DISCUSSION}

Various parameters of fresh as well as incubated eggs were noted daily and are presented in Table 1.

Recently, the work on incubation of Japanese quail eggs (Coturnix japonica) stored in domestic refrigerator is limited to the work of Vasconcelos de Moraes et al. (2008). During present study, it was recorded that as the incubation progresses, egg weight slowly decreases day by day. There is also consistent decrease in shell weight from $2.00 \mathrm{~g}$ to $0.35 \pm 0.59 \mathrm{~g}$ during the study period of 18 days incubation period. Mohmond and Coleman (1967) reported the thickness of the shell and shell membrane to be respectively 0.197 and $0.063 \mathrm{~mm}$ which was similar to our recorded results. The present study showed the decrease in shell weight during the period of experimentation i.e. from day 1 to day 18 showed that the growing embryo has to exert less pressure before hatching the egg and it is utilizing some of its contents for its growth.

\section{REFERENCES}

Charde, P.N. (1998).Influence of exogenous pharmacological compounds on Reproductive Biology of Coturnix coromandelica. PhD Thesis, Nagpur University, Nagpur

Mohmond, T.H. and Coleman, T. H. (1967).A comparison of the proportion of component parts of Bobwhite and Coturnix eggs. Poultry Sci., 46:1168-1171.

Padgett, C.A. and Ivey, W. D. (1959).C oturnix quail as a laboratory research animal. Science, 129 (3344):267-268. 
Table 1. Changes recorded in egg parameters of Japanese quail during 18 days incubation period (values are Mean \pm S.E.).

\begin{tabular}{|c|c|c|c|c|c|}
\hline Day & $\begin{array}{l}\text { Egg weight before } \\
\text { incubation (gm) }\end{array}$ & $\begin{array}{l}\text { Egg weight after } \\
\text { incubation (gm) }\end{array}$ & $\begin{array}{l}\text { Shell weight } \\
\text { (gm) }\end{array}$ & $\begin{array}{l}\text { Yolk weight } \\
\text { (gm) }\end{array}$ & $\begin{array}{c}\text { Embryo } \\
\text { weight (gm) }\end{array}$ \\
\hline 0 & $13.28 \pm 1.75$ & -- & 2.00 & $4.98 \pm 0.58$ & -- \\
\hline 1 & $12.05 \pm 1.22$ & $11.79 \pm 1.21$ & $1.98 \pm 0.87$ & $4.16 \pm 0.62$ & $0.089 \pm 0.65$ \\
\hline 2 & $12.01 \pm .56$ & $11.39 \pm 0.87$ & $1.94 \pm 0.76$ & $6.13 \pm 0.75$ & $0.095 \pm 0.79$ \\
\hline 3 & $10.46 \pm 1.78$ & $10.11 \pm 0.96$ & $1.90 \pm 0.67$ & $5.03 \pm 0.67$ & $1.01 \pm 0.69$ \\
\hline 4 & $10.12 \pm 1.65$ & $09.78 \pm 0.97$ & $1.89 \pm 0.56$ & $6.16 \pm 0.78$ & $1.21 \pm 0.75$ \\
\hline 5 & $10.24 \pm 0.78$ & $09.82 \pm 0.98$ & $1.84 \pm 0.45$ & $5.14 \pm 0.69$ & $1.45 \pm 0.69$ \\
\hline 6 & $12.80 \pm 1.23$ & $11.60 \pm 1.45$ & $1.90 \pm 0.86$ & $5.83 \pm 0.71$ & $1.51 \pm 0.78$ \\
\hline 7 & $11.91 \pm 1.75$ & $11.34 \pm 1.42$ & $1.81 \pm 0.78$ & $5.32 \pm 0.78$ & $1.62 \pm 0.71$ \\
\hline 8 & $11.92 \pm 1.67$ & $10.75 \pm 1.32$ & $1.80 \pm 0.75$ & $4.68 \pm 0.87$ & $1.38 \pm 0.81$ \\
\hline 9 & $12.04 \pm 1.56$ & $11.54 \pm 1.22$ & $1.80 \pm 0.67$ & $3.53 \pm 0.95$ & $2.35 \pm 0.91$ \\
\hline 10 & $11.98 \pm 1.23$ & $11.18 \pm 1.15$ & $1.76 \pm 0.71$ & $2.36 \pm 0.79$ & $2.38 \pm 0.89$ \\
\hline 11 & $11.72 \pm 1.12$ & $11.08 \pm 1.11$ & $1.71 \pm 0.71$ & $2.29 \pm 0.59$ & $2.46 \pm 0.86$ \\
\hline 12 & $10.12 \pm 1.65$ & $09.32 \pm 1.16$ & $1.70 \pm 0.69$ & $2.20 \pm 0.61$ & $3.88 \pm 0.78$ \\
\hline 13 & $10.21 \pm 1.78$ & $09.82 \pm 1.14$ & $1.60 \pm 0.65$ & $1.19 \pm 0.79$ & $4.42 \pm 0.65$ \\
\hline 14 & $10.88 \pm 1.64$ & $10.15 \pm 1.13$ & $1.59 \pm 0.59$ & $0.46 \pm 0.81$ & $5.53 \pm 0.71$ \\
\hline 15 & $10.24 \pm 1.67$ & $07.39 \pm 1.12$ & $1.21 \pm 0.65$ & $0.31 \pm 0.79$ & $5.55 \pm 0.72$ \\
\hline 16 & $10.08 \pm 1.76$ & $07.49 \pm 1.13$ & $0.84 \pm 0.59$ & $0.58 \pm 0.87$ & $5.58 \pm 0.69$ \\
\hline 17 & $10.46 \pm 1.78$ & $09.72 \pm 1.14$ & $0.56 \pm 0.61$ & $0.12 \pm 0.95$ & $7.44 \pm 0.79$ \\
\hline 18 & $12.12 \pm 1.23$ & $09.25 \pm 1.12$ & $0.35 \pm 0.59$ & -- & $7.75 \pm 0.81$ \\
\hline
\end{tabular}

Reese, E.P. and Reese, T. W. (1962).The quail Coturnix coturnix as a laboratory animal. J ournal of Experimental A nalysis of Behaviour, 5(2):265-270.

Vasconcelos de Moraes, T.G., Moura Romao, J., Evangelista da Silva, E., Maciel Cardoso, W. and Buxade Carbo, C. (2008). Incubation of Japanese quail eggs (C oturnix japonica) stored in domestic refrigerator. Livestock Research for Rural D evelopment, 20 (10): Article \# 164.
Wilson, W.O., Ursula K., Abbott and Hans Abplanalp (1961). Evaluation of coturnix (Japanes Quail) as pilot animal for poultry. Poultry Sci., 40: 651-657.

Woodard, A.E. and Wilson, W.O. (1963).Egg and yolk weight of Coturnix quail (Coturnix coturnix japonica) in relation to position in egg sequences. Poultry Sci., 42: 544-545. 